\title{
Efek Konseling Menggunakan Brief Counseling 5A Modifikasi Disertai Pesan Motivasional Farmasis dalam Peningkatan Perilaku dan Outcome Klinik Pasien Diabetes Melitus dengan Hipertensi Rawat Jalan di RSUD Panembahan Senopati, Bantul
}

\section{Ginanjar Z. Saputri ${ }^{1}$, Akrom ${ }^{1}$, Muhammad Muhlis ${ }^{2}$, Ainun Muthoharoh ${ }^{2}$}

${ }^{1}$ Fakultas Farmasi, Universitas Ahmad Dahlan, Yogyakarta, Indonesia,

${ }^{2}$ Prodi Sarjana Farmasi, STIKES Muhammadiyah Pekajangan, Pekalongan, Indonesia

\begin{abstract}
Abstrak
Diabetes melitus (DM) dengan hipertensi merupakan penyakit komplikasi sindrom metabolik dengan terapi lebih dari satu obat. Selain faktor pengetahuan, faktor perilaku dan motivasi dari luar dapat menjadi salah satu faktor kebosanan pasien dalam menjalani terapi jangka panjang. Dibutuhkan edukasi dan motivasi untuk kepatuhan perilaku berobat dalam mencapai target terapi pasien DM-hipertensi. Penelitian ini bertujuan untuk mengetahui pengaruh brief-counseling 5A modifikasi oleh apoteker dan dukungan motivasi pesan singkat dalam meningkatkan perilaku dan outcome klinis pasien DM-hipertensi rawat jalan di RSUD Panembahan Senopati Bantul, Yogyakarta. Penelitian ini menggunakan metode kuasi-eksperimental dengan desain prepost. Pengambilan data dilakukan secara prospektif selama periode Maret-Mei 2017. Sebanyak 99 orang yang memenuhi kriteria inklusi dibagi menjadi 3 kelompok yang terdiri dari 33 pasien. Tingkat perilaku pasien diukur melalui wawancara menggunakan kuesioner perilaku pasien DM-hipertensi, sedangkan data outcome klinis pasien diambil dari data rekam medis. Hasil penelitian ini menunjukkan bahwa proporsi tingkat perilaku pada tahap aksi kelompok perlakuan 1 (brief counseling 5A modifikasi) dan 2 (brief counseling 5A modifikasi + SMS motivasi) lebih besar (masing-masing sebesar 21,2\%) dibandingkan kelompok kontrol $(12,1 \%)$. Pemberian brief counseling 5A modifikasi dapat menurunkan tekanan darah sistolik sebesar $8,36 \pm 12,21 \mathrm{mmHg}(\mathrm{p}=0,000)$, diastolik $2,42 \pm 10,69 \mathrm{mmHg}(\mathrm{p}=0,202)$ dan gula darah sewaktu (GDS) 24,66 $\mathrm{mg} / \mathrm{dL}(\mathrm{p}=0,017)$. Pemberian brief counseling 5A modifikasi + SMS motivasi dapat menurunkan tekanan darah sistolik sebesar $8,79 \pm 17,32 \mathrm{mmHg}(\mathrm{p}=0,012)$, diastolik $5,0 \pm 9,92 \mathrm{mmHg}(\mathrm{p}=0,007)$, dan GDS 24,91 $\mathrm{mg} / \mathrm{dL}(\mathrm{p}=0,079)$. Kelompok brief counseling 5A modifikasi disertai pesan (SMS) motivasi lebih efektif dalam meningkatkan perilaku pasien dan pengontrolan outcome klinik dibandingkan kelompok kontrol maupun brief counseling $5 \mathrm{~A}$ modifikasi.
\end{abstract}

Kata kunci: Brief counseling 5A modifikasi, diabetes melitus, hipertensi, pesan motivatif (SMS motivasi)

\section{Effect of Brief Counseling 5A Modification and Pharmacist Motivation Message in Improving Behavior and Clinical Outcome of Diabetes Mellitus- Hypertensive Outpatients in Panembahan Senopati Hospital, Bantul}

\begin{abstract}
Diabetes mellitus (DM) with hypertension is a complicating disease of metabolic syndrome with more than one drug therapy. Aside from knowledge, behavior and motivation also can be factors that trigger patient's boredom in undergoing long-term therapy. Education and motivation are needed for adherence to treatment in order to achieve therapeutic target of DM-hypertensive patients. This study aimed to determine the effect of brief counseling 5A modification by pharmacists and short message (SMS) motivation to improve behavior and clinical outcomes of DM-hypertensive outpatients at Panembahan Senopati Hospital, Bantul, Yogyakarta. This study used a quasi-experimental method with pre-post design, and data collection was conducted prospectively during the period of March-May 2017. A total of 99 patients who were eligible for inclusion criteria were divided into 3 groups consisting of 33 patients. Level of patient's behavior was measured through interviews using behavioral questionnaire of DM-hypertensive patients, while the patient's clinical outcome was taken from medical record. The results of this study indicate that the proportion of behavioral levels in action stage of group 1 (brief counseling 5A modification) and group 2 (brief counseling $5 \mathrm{~A}$ modification + SMS motivation) were greater $(21.2 \%$ each) than control group $(12.1 \%)$. Brief counseling 5A modification could reduce systolic blood pressure by $8.36 \pm 12.21 \mathrm{mmHg}(\mathrm{p}=0.000)$, diastolic $2.42 \pm 10.69$ $\mathrm{mmHg}(\mathrm{p}=0.202)$ and blood glucose level $24.66 \mathrm{mg} / \mathrm{dL}(\mathrm{p}=0.017)$. Brief counseling 5A modification with SMS motivation could reduce systolic blood pressure by $8.79 \pm 17.32 \mathrm{mmHg}(\mathrm{p}=0.012)$, diastolic $5.0 \pm 9.92$ $\mathrm{mmHg}(\mathrm{p}=0.007)$, and blood glucose level $24.91 \mathrm{mg} / \mathrm{dL}(\mathrm{p}=0.079)$. The brief counseling 5 A modification group with SMS motivation was more effective in improving patient behavior and controlling clinical outcomes compared to the control group and brief counseling $5 \mathrm{~A}$ modification group.
\end{abstract}

Keywords: Brief counseling 5A modification, diabetes mellitus, hypertension, motivational message (SMS)

Korespondensi: Ginanjar Z. Saputri, M.Sc., Apt., Fakultas Farmasi, Universitas Ahmad Dahlan, Yogyakarta, DI Yogyakarta 55164, Indonesia, email: zukhruf.alparslan@gmail.com

Naskah diterima: 22 Januari 2019, Diterima untuk diterbitkan: 11 Februari 2019, Diterbitkan: 1 Maret 2019 


\section{Pendahuluan}

Diabetes melitus (DM) diperkirakan menjadi salah satu penyebab kematian di dunia secara global pada tahun 2030. ${ }^{1}$ Mayoritas pasien DM merupakan DM tipe 2. ${ }^{2}$ Kadar gula darah yang tidak terkontrol dapat menimbulkan komplikasi akut maupun kronik, salah satunya hipertensi. Lebih dari $80 \%$ pasien DM tipe 2 mempunyai risiko kematian dan komplikasi penyakit kardiovaskuler yang disebabkan oleh adanya komplikasi hipertensi. ${ }^{3}$ Diabetes adalah penyakit kronik dengan multifaktor yang dapat memengaruhi self-management pasien dan pengontrolan outcome klinik. Faktor tersebut antara lain seperti rendahnya pengetahuan pasien mengenai manajemen DM, rendahnya tingkat kepatuhan terapi, dan modifikasi lifestyle. ${ }^{4-6}$

Edukasi pasien merupakan salah satu cara yang efektif dalam peningkatan kepatuhan terapi dan manajemen diabetes. ${ }^{7,8}$ Chow et al. (2015) dalam hasil penelitiannya menyebutkan, intervensi farmasis dalam bentuk pemberian edukasi dapat meningkatkan pengetahuan dan perilaku kepatuhan pasien DM. Hal ini sejalan dengan penelitian sebelumnya yang menyebutkan bahwa peran farmasis klinik merupakan salah satu jalan dalam edukasi dan motivasi pasien DM. Farmasis memiliki peran dalam edukasi manajemen terapi dan edukasi lifestyle pada pasien DM. ${ }^{8-11}$ Bahkan peran edukasi farmasi menunjukkan pengaruh positif dalam pengontrolan outcome klinik. $^{12}$

Pengembangan model konseling farmasi dalam bentuk brief couseling 5A modifikasi disertai dengan SMS motivasional pada pasien hipertensi telah dilakukan sebelumnya di RS PKU Muhammadiyah Bantul, dan hasilnya menunjukkan adanya peningkatan kepatuhan antihipertensi, pengontrolan tekanan darah dan peningkatan kualitas hidup. ${ }^{13}$ Keterbatasan pada penelitian sebelumnya yaitu pemberian pesan SMS motivasional yang sederhana, yang pada penelitian ini dikembangkan kembali pada pasien DM-hipertensi. Adapun brief counseling 5A modifikasi ialah pengembangan yang disesuaikan dengan konten edukasi pada pasien DM-hipertensi. Berdasarkan hal ini, penelitian ini bertujuan untuk mengetahui pengaruh brief counseling 5A modifikasi disertai SMS motivasional pada pasien DMhipertensi rawat jalan di RSUD Panembahan Senopati, Bantul, Yogyakarta.

\section{Metode}

Penelitian ini telah diajukan dan disetujui oleh Komite Etik Penelitian (KEP) Universitas Ahmad Dahlan dengan nomor 011610143. Penelitian ini menggunakan desain kuasi eksperimental pre-post dengan pengambilan data secara prospektif. Penelitian dilakukan selama periode Maret-Mei tahun 2017 di Poli Penyakit Dalam RSUD Panembahan Senopati, Bantul. Pemberian intervensi yang berupa brief counseling 5A modifikasi dilakukan oleh apoteker yang telah terstandarisasi.

Pengembangan konten isi brief counseling 5A modifikasi sebagai intervensi farmasis dilakukan melalui forum grup diskusi (FGD), begitu pula dengan kuesioner pengukuran perilaku pasien DM-Hipertensi. Selanjutnya kuesioner dilakukan validasi expert oleh dokter, apoteker, dan psikologi klinis. Uji validasi dan reliabilitas telah dilakukan pada 37 pasien DM-hipertensi sesuai kriteria inklusi dengan nilai r $>0,33$ dan nilai Cronbach alpha adalah 0,722 . Kuesioner perilaku didesain berupa jawaban "ya" dan "tidak" (skor jawaban "ya" $=1$ dan jawaban "tidak" $=0$ )

Pesan melalui short text message (SMS) ataupun Whatsapp (WA) telah disusun dan dilakukan review atau validasi expert. Pesan motivasi didesain dalam tiga macam pesan berbeda. Pesan 1 sebagai pengingat minum obat (reminder), pesan 2 sebagai motivasi tentang pentingnya pasien dalam keluarga, dan pesan 3 sebagai motivasi dalam pendekatan religiusitas (agama Islam) dalam menerima 
penyakit dan ikhtiar dalam berobat. Ketiga pesan motivasi tersebut dikirimkan secara bergantian setiap harinya hingga 10-14 hari.

Rekrutmen subjek didasarkan pada kriteria inklusi, yaitu pasien yang didiagnosis DMhipertensi berusia 18-70 tahun, mengonsumsi minimal 1 obat antidiabetik oral dan 1 obat anti hipertensi, memiliki media komunikasi (telepon genggam), tidak buta huruf dan tidak tuli, serta kooperatif, sedangkan kriteria eksklusi adalah pasien yang hamil, buta huruf dan tuli. Sebanyak 99 orang yang memenuhi kriteria inklusi dan telah menyetujui informed consent dibagi ke dalam tiga kelompok yang terdiri dari 33 pasien yaitu: kelompok kontrol (usual care), kelompok perlakuan 1 (mendapat brief counseling 5A modifikasi), dan kelompok perlakuan 2 (mendapat brief counseling 5A modifikasi disertai pesan motivatif (SMS motivasi)). Teknik sampling menggunakan teknik random sederhana. Tingkat perilaku pasien diukur dengan melalui wawancara menggunakan kuesioner perilaku pasien DMhipertensi, sedangkan data tentang outcome klinis pasien berupa kadar gula darah sewaktu (GDS) dan tekanan darah (TD) diambil dari catatan rekam medis. Analisis statistik yang digunakan adalah uji Chi-Square, one way Anova, dan Post Hoc.

\section{Hasil}

Berdasarkan data karakteristik pasien pada Tabel 1, mayoritas pasien penelitian ini adalah perempuan, baik pada kelompok perlakuan 1 (brief counseling) sebesar 24,2\% maupun kelompok perlakuan 2 (brief counseling + pesan motivatif) sebesar 21,2\%. Mayoritas subjek telah menikah pada kelompok perlakuan 1 dan 2 , kecuali pada kelompok kontrol terdapat 3 pasien (3\%) yang belum menikah. Usia yang mendominasi pada masing-masing kelompok yaitu pada usia 56-65 tahun dengan jumlah masing-masing 18 pasien $(18,2 \%)$ pada setiap

Tabel 1 Karakteristik Subjek Penelitian Pasien Diabetes Melitus-Hipertensi di RSUD Panembahan Senopati Bantul Yogyakarta

\begin{tabular}{|c|c|c|c|c|c|c|c|}
\hline \multirow[t]{2}{*}{ Karakteristik Pasien } & \multicolumn{2}{|c|}{$\begin{array}{l}\text { Kelompok } \\
\text { Usual Care } \\
(\mathrm{N}=33)\end{array}$} & \multicolumn{2}{|c|}{$\begin{array}{c}\text { Kelompok } \\
\text { Brief Counseling } \\
(\mathbf{N}=33)\end{array}$} & \multicolumn{2}{|c|}{$\begin{array}{c}\text { Kelompok } \\
\text { Brief Counseling + SMS } \\
\text { Motivasi }(\mathrm{N}=33)\end{array}$} & \multirow[t]{2}{*}{ Nilai $p$} \\
\hline & $\bar{n}$ & $\%$ & $n$ & $\%$ & n & $\%$ & \\
\hline \multicolumn{8}{|l|}{ Jenis Kelamin } \\
\hline Laki-laki & 16 & 16,2 & 9 & 9,1 & 12 & 12,1 & \multirow[t]{2}{*}{0,203} \\
\hline Perempuan & 17 & 12,2 & 24 & 24,2 & 21 & 21,2 & \\
\hline \multicolumn{8}{|l|}{ Status Menikah } \\
\hline Menikah & 30 & 30,3 & 33 & 33,3 & 33 & 33,3 & \multirow[t]{2}{*}{0,045} \\
\hline Belum menikah & 3 & 3,0 & 0 & 0,0 & 0 & 0,0 & \\
\hline \multicolumn{8}{|l|}{ Usia (tahun) } \\
\hline $36-45$ & 1 & 1,0 & 1 & 1,0 & 3 & 3,0 & \multirow[t]{4}{*}{0,882} \\
\hline $46-55$ & 5 & 5,1 & 4 & 4,0 & 6 & 6,1 & \\
\hline $56-65$ & 18 & 18,2 & 18 & 18,2 & 18 & 18,2 & \\
\hline$>65$ & 9 & 9,1 & 10 & 10,1 & 8 & 8,1 & \\
\hline \multicolumn{8}{|l|}{ Pendidikan } \\
\hline $\mathrm{SD}$ & 10 & 10,1 & 10 & 10,1 & 3 & 3,0 & \multirow[t]{5}{*}{0,101} \\
\hline SMP & 3 & 3,0 & 7 & 7,1 & 6 & 6,1 & \\
\hline SMA & 11 & 11,1 & 7 & 7,1 & 16 & 16,2 & \\
\hline $\mathrm{D} 1-\mathrm{S} 1$ & 8 & 8,1 & 6 & 6,1 & 8 & 8,1 & \\
\hline $\mathrm{S} 2$ & 1 & 1,0 & 3 & 3,0 & 0 & 0,0 & \\
\hline
\end{tabular}


Tabel 1 Karakteristik Subjek Penelitian Pasien Diabetes Melitus-Hipertensi di RSUD Panembahan Senopati Bantul Yogyakarta (Lanjutan)

\begin{tabular}{|c|c|c|c|c|c|c|c|}
\hline \multirow[t]{2}{*}{ Karakteristik Pasien } & \multicolumn{2}{|c|}{$\begin{array}{l}\text { Kelompok } \\
\text { Usual Care } \\
(\mathbf{N}=33)\end{array}$} & \multicolumn{2}{|c|}{$\begin{array}{c}\text { Kelompok } \\
\text { Brief Counseling } \\
(\mathbf{N}=33)\end{array}$} & \multicolumn{2}{|c|}{$\begin{array}{c}\text { Kelompok } \\
\text { Brief Counseling }+ \text { Pesan } \\
(\mathrm{N}=33)\end{array}$} & \multirow[t]{2}{*}{ Nilai $p$} \\
\hline & $\mathbf{n}$ & $\%$ & $\mathbf{n}$ & $\%$ & $\mathbf{n}$ & $\%$ & \\
\hline \multicolumn{8}{|l|}{ Pekerjaan } \\
\hline Bekerja & 14 & 14,1 & 8 & 8,1 & 11 & 11,1 & 0,293 \\
\hline Tidak bekerja & 19 & 19,2 & 25 & 25,3 & 22 & 22,2 & \\
\hline \multicolumn{8}{|l|}{ Biaya Kesehatan } \\
\hline Swadaya & 1 & 1,0 & 0 & 0,0 & 0 & 0,0 & 0,364 \\
\hline BPJS & 32 & 32,3 & 33 & 33,3 & 33 & 33,3 & \\
\hline \multicolumn{8}{|l|}{ Riwayat Diabetes Melitus } \\
\hline Ada & 14 & 14,1 & 15 & 15,2 & 14 & 14,1 & 0,701 \\
\hline Tidak ada & 19 & 19,2 & 17 & 17,2 & 19 & 19,2 & \\
\hline \multicolumn{8}{|l|}{ Lama Diabetes Melitus } \\
\hline $1-5$ tahun & 13 & 13,1 & 8 & 8,1 & 7 & 7,1 & 0,350 \\
\hline $6-10$ tahun & 8 & 8,1 & 9 & 9,1 & 12 & 12,1 & \\
\hline $11-15$ tahun & 5 & 5,1 & 5 & 5,1 & 8 & 8,1 & \\
\hline 16-20 tahun & 6 & 6,1 & 7 & 7,1 & 2 & 2,0 & \\
\hline$>20$ tahun & 1 & 1,0 & 4 & 4,0 & 4 & 4,0 & \\
\hline \multicolumn{8}{|l|}{ Status Merokok } \\
\hline $\mathrm{Ya}$ & 2 & 2,0 & 1 & 1,3 & 1 & 1,0 & 0,771 \\
\hline Tidak & 31 & 31,3 & 32 & 32,3 & 32 & 32,3 & \\
\hline \multicolumn{8}{|l|}{ Body Mass Index (BMI) } \\
\hline$<18,5$ & 3 & 3,0 & 1 & 1,0 & 0 & 0,0 & 0,298 \\
\hline $18,5-24,9$ & 18 & 18,2 & 17 & 17,2 & 18 & 18,2 & \\
\hline $25-29,9$ & 11 & 11,1 & 9 & 9,1 & 11 & 11,1 & \\
\hline $30-34,9$ & 1 & 1,0 & 6 & 6,1 & 4 & 4,0 & \\
\hline \multicolumn{8}{|l|}{ Diet } \\
\hline Garam & 0 & 0,0 & 1 & 1,0 & 0 & 0,0 & 0,630 \\
\hline Gula/karbohidrat & 1 & 1,0 & 0 & 0,0 & 0 & 0,0 & \\
\hline Garam+Gula & 12 & 12,1 & 13 & 13,1 & 14 & 14,1 & \\
\hline Semua & 19 & 19,2 & 19 & 19,2 & 19 & 19,2 & \\
\hline Tidak & 1 & 1,0 & 0 & 0,0 & 0 & 0,0 & \\
\hline \multicolumn{8}{|l|}{ Olahraga } \\
\hline 1x1 per hari & 15 & 15,2 & 15 & 15,2 & 19 & 19,2 & 0,382 \\
\hline $1 \times 1$ per minggu & 9 & 9,1 & 12 & 12,1 & 10 & 10,1 & \\
\hline $1 \times 1$ per bulan & 4 & 4,0 & 4 & 4,0 & 0 & 0,0 & \\
\hline Tidak & 5 & 5,1 & 2 & 2,0 & 4 & 4,0 & \\
\hline \multicolumn{8}{|l|}{ Jumlah Obat } \\
\hline 1OAD+1OAHT & 7 & 7,1 & 4 & 4,0 & 7 & 7,1 & 0,543 \\
\hline$>1 \mathrm{OAD}+1 \mathrm{OAHT}$ & 26 & 26,3 & 29 & 29,3 & 26 & 26,3 & \\
\hline
\end{tabular}


kelompok. Tingkat pendidikan pasien pada kelompok kontrol dan perlakuan 2 didominasi pada tingkat SMA, berturut-turut sebanyak $11,1 \%$ dan $16,2 \%$, sedangkan pada kelompok perlakuan 1 didominasi oleh pasien tingkat SD $(10,1 \%)$. Mayoritas pasien tidak bekerja pada kelompok kontrol sebesar 19,2\%, perlakuan 1 sebesar $25,3 \%$, dan perlakuan 2 sebesar $22,2 \%$. Mayoritas pasien membayar dengan asuransi pemerintah (BPJS) dan hanya ada 1 pasien yang membayar biaya kesehatan secara swadaya yaitu pada kelompok kontrol $(1 \%)$.

Pada penelitian ini, dilakukan penilaian ada atau tidaknya faktor risiko kardiovaskular yaitu riwayat diabetes, kebiasaan merokok, berat badan pasien, dan durasi DM yang diderita oleh pasien. Mayoritas pasien tidak memiliki riwayat DM pada semua kelompok, dengan masing-masing sejumlah $19,2 \%$ pada kelompok kontrol dan kelompok perlakuan 2 , dan $17,2 \%$ pada kelompok perlakuan 1 . Kelompok kontrol didominasi oleh pasien yang telah mempunyai penyakit DM selama 1-5 tahun sebanyak 13 pasien $(13,1 \%)$, dan kelompok perlakuan 1 dan 2 didominasi oleh pasien yang telah mempunyai penyakit DM selama 6-10 tahun, berturut-turut sebanyak
$9,1 \%$ dan $12,1 \%$.

Berdasarkan hasil uji analisis statistik ChiSquare, diperoleh karakteristik pasien DMhipertensi antara kelompok kontrol, kelompok perlakuan 1, dan kelompok perlakuan 2 tidak memiliki perbedaan yang signifikan ( $\mathrm{p}>0,05)$ pada jenis kelamin $(0,203)$, usia $(0,882)$, pendidikan $(0,101)$, pekerjaan $(0,293)$, biaya kesehatan $(0,364)$, riwayat DM $(0,701)$, durasi DM $(0,350)$, status merokok $(0,771)$, body mass index (BMI) $(0,298)$, diet $(0,630)$, olahraga $(0,382)$, serta jumlah obat yang dikonsumsi setiap harinya $(0,543)$. Namun demikian, ada perbedaan signifikan $(\mathrm{p}<0,05)$ pada status menikah pasien DM-hipertensi $(0,045)$ antara kelompok kontrol, kelompok perlakuan 1, dan kelompok perlakuan 2 .

Tingkat perilaku pasien masing-masing kelompok dapat dilihat pada Tabel 2. Dari hasil penilaian awal, tingkat perilaku pasien antara kelompok kontrol, kelompok perlakuan 1 dan perlakuan 2 tidak berbeda bermakna yaitu $0,811(\mathrm{p}>0,05)$. Pada akhir penelitian, proporsi tingkat perilaku pada tahap aksi kelompok perlakuan 1 dan 2 lebih besar dibandingkan dengan kelompok kontrol yaitu masing-masing sebanyak 21 pasien $(21,2 \%)$ pada kelompok perlakuan 1 dan 2 sedangkan

Tabel 2 Hubungan antara Tingkat Perlakuan dengan Tingkat Perilaku Pasien Diabetes dengan Hipertensi pada Kunjungan Pertama (Pre) dan Kunjungan Kedua (Post)

\begin{tabular}{|c|c|c|c|c|c|c|c|c|c|c|}
\hline \multirow{3}{*}{$\begin{array}{l}\text { Tingkat } \\
\text { Perilaku }\end{array}$} & \multicolumn{8}{|c|}{ Tingkat Perlakuan } & \multirow{3}{*}{$\mathbf{n}$} & \multirow{3}{*}{ Nilai $p$} \\
\hline & \multicolumn{2}{|c|}{ Prekontemplasi } & \multicolumn{2}{|c|}{ Kontemplasi } & \multicolumn{2}{|c|}{ Persiapan } & \multicolumn{2}{|c|}{ Aksi } & & \\
\hline & $n$ & $\%$ & $n$ & $\%$ & $n$ & $\%$ & $n$ & $\%$ & & \\
\hline \multicolumn{11}{|l|}{ Pre } \\
\hline Kontrol & 9 & 9,1 & 6 & 6,1 & 6 & 6,1 & 12 & 12,1 & 33 & 0,811 \\
\hline Perlakuan 1 & 7 & 7,1 & 6 & 6,1 & 5 & 5,1 & 15 & 15,2 & 33 & \\
\hline Perlakuan 2 & 5 & 5,1 & 4 & 4,0 & 8 & 8,1 & 16 & 16,2 & 33 & \\
\hline Total & 21 & 21,3 & 14 & 16,2 & 19 & 19,3 & 43 & 43,5 & 99 & \\
\hline \multicolumn{11}{|l|}{ Post } \\
\hline Kontrol & 5 & 5,1 & 9 & 9,1 & 7 & 7,1 & 12 & 12,1 & 33 & $0,007^{*}$ \\
\hline Perlakuan 1 & 1 & 1,0 & 1 & 1,0 & 10 & 10,1 & 21 & 21,2 & 33 & \\
\hline Perlakuan 2 & 0 & 0,0 & 4 & 4,0 & 8 & 8,1 & 21 & 21,2 & 33 & \\
\hline Total & 6 & 6,1 & 13 & 13,1 & 24 & 24,3 & 56 & 56,5 & 99 & \\
\hline
\end{tabular}


Tabel 3 Total Skor Tingkat Perilaku pada Kunjungan Pertama (Pre) dan Kunjungan Kedua (Post)

\begin{tabular}{lcccccc}
\hline \multirow{2}{*}{$\begin{array}{c}\text { Total Skor } \\
\text { Tingkat Perilaku }\end{array}$} & $\begin{array}{c}\text { Kontrol } \\
\mathbf{N = 3 3}\end{array}$ & $\begin{array}{c}\text { Perlakuan 1 } \\
\mathbf{N = 3 3}\end{array}$ & $\begin{array}{c}\text { Perlakuan 2 } \\
\mathbf{N = 3 3}\end{array}$ & \multirow{2}{*}{ Nilai p(1) } & Nilai p(2) & Nilai p(3) \\
\cline { 2 - 4 } & Mean \pm SD & Mean \pm SD & Mean \pm SD & & & \\
\hline Pre & $10,64 \pm 1,45$ & $10,88 \pm 1,29$ & $10,88 \pm 1,69$ & 0,510 & 0,510 & 1,000 \\
Post & $10,88 \pm 1,16$ & $11,45 \pm 0,90$ & $11,30 \pm 11,21$ & $0,038^{*}$ & 0,124 & 0,581
\end{tabular}

Keterangan: Nilai $\mathrm{p}(1)=$ nilai signifikansi antara kelompok kontrol dan perlakuan 1; Nilai $\mathrm{p}(2)=$ Nilai signifikansi antara kelompok kontrol dan perlakuan 2; Nilai $\mathrm{p}(3)=$ Nilai signifikansi antara kelompok perlakuan 1 dan $2 ; *=$ nilai $\mathrm{p}<0,05$. Analisis menggunakan uji Anova dengan Post-Hoc test.

pada kelompok kontrol sebanyak 12 pasien (12,1\%). Pada kelompok kontrol hanya terjadi perubahan pada perilaku kontemplasi dan persiapan, hal ini disebabkan pada kelompok kontrol tidak diberikan brief counseling dari apoteker.

Berdasarkan Tabel 3, diketahui total skor tingkat perilaku pada kunjungan kedua antara kelompok kontrol, kelompok perlakuan 1, dan perlakuan 2 berturut-turut yaitu $10,88 \pm 1,16$, $11,45 \pm 0,90$, dan $11,30 \pm 11,21$. Berdasarkan uji Anova melalui hasil uji Post Hoc, terdapat perbedaan yang signifikan antara kelompok kontrol dengan kelompok $1(\mathrm{p}=0,038)$ pada kunjungan kedua. Sebaliknya, tidak terdapat perbedaan signifikan antara kelompok kontrol dengan kelompok perlakuan 2 dan kelompok perlakuan 1 dengan perlakuan $2(0,0581)$. Hal tersebut menunjukkan bahwa pemberian intervensi brief counseling 5A modifikasi dan pesan motivatif memberikan pengaruh perubahan perilaku berobat pada pasien DMhipertensi, meskipun tidak ada perbedaan yang signifikan terhadap kelompok kontrol (usual care) maupun kelompok perlakuan 1 $(\mathrm{p}=0,124)$.

Pengukuran kadar gula darah sewaktu
(GDS) dan tekanan darah (TD) dilakukan untuk melihat outcome klinis pasien DMhipertensi yang ditunjukkan pada Tabel 4. Data baseline atau penilaian awal menunjukkan rata-rata tekanan darah sistolik (TDS) pasien pada kelompok kontrol, kelompok perlakuan 1, dan perlakuan 2 memiliki nilai $\mathrm{p}=0,412$, nilai rata-rata tekanan darah diastolik (TDD) ketiga kelompok memiliki nilai $\mathrm{p}=0,797$, dan nilai rata-rata GDS ketiga kelompok memiliki nilai $p=0,288$. Ketiga rata-rata outcome klinis menunjukkan tidak terdapat perbedaan yang signifikan $(\mathrm{p}>0,05)$.

Dari Tabel 5, dapat dilihat bahwa terdapat penurunan TDS dari kelompok kontrol pada kunjungan pertama (pre), yakni dari semula $139,24 \pm 15,53 \mathrm{mmHg}$ menjadi $132,87 \pm 12,81$ mmHg $(p=0,014)$ pada kunjungan kedua (post). Rata-rata TDS kelompok perlakuan 1 juga mengalami penurunan dari semula $135,3 \pm 13,4 \mathrm{mmHg}$ menjadi $126,9 \pm 8,9 \mathrm{mmHg}$ $(\mathrm{p}=0,000)$, begitu pula kelompok perlakuan 2 yang mengalami penurunan dari semula $134,54 \pm 16,78 \mathrm{mmHg}$ menjadi $125,45 \pm 16,78$ $\mathrm{mmHg}(\mathrm{p}=0,012)$. Penurunan rata-rata TDS ketiga kelompok ini menunjukkan perbedaan yang signifikan $(p<0,05)$.

Tabel 4 Penilaian Data Awal (Baseline) Rata-Rata Tekanan Darah dan Gula Darah Pasien

\begin{tabular}{lcccc}
\hline \multirow{2}{*}{ Variabel Penelitian } & Kontrol & Perlakuan $\mathbf{1}$ & Perlakuan 2 \\
& $\mathbf{N}=\mathbf{3 3}$ & $\mathbf{N = 3 3}$ & $\mathbf{N = 3 3}$ & \multirow{2}{*}{ Nilai p } \\
\cline { 2 - 4 } & Mean \pm SD & Mean \pm SD & Mean \pm SD & \\
\hline Tekanan darah sistolik $(\mathrm{mmHg})$ & $139,24 \pm 15,53$ & $135,30 \pm 13,40$ & $134,54 \pm 16,78$ & 0,412 \\
Tekanan darah diastolik (mmHg) & $84,70 \pm 8,30$ & $83,64 \pm 8,20$ & $83,48 \pm 7,34$ & 0,797 \\
Gula darah sewaktu (mg/dL) & $203,50 \pm 68,50$ & $200,20 \pm 87,90$ & $173,90 \pm 90,80$ & 0,288 \\
\hline Keterangan: Nilai p=nilai signifikansi. Analisis menggunakan uji compare means one way Anova. & &
\end{tabular}


Tabel 5 Hubungan antara Tingkat Perlakuan dengan Tekanan Darah Sistolik dan Diastolik dan Kadar Gula Darah Pasien pada Kunjungan Pertama (Pre) dan Kunjungan Kedua (Post)

\begin{tabular}{clccc}
\hline Kelompok & \multicolumn{1}{c}{ Variabel } & Pre & Post & Nilai p \\
\hline \multirow{2}{*}{ Kontrol } & Tekanan darah sistolik & $139,24 \pm 15,53$ & $132,87 \pm 12,81$ & $0,014^{*}$ \\
& Tekanan darah diastolik & $84,70 \pm 8,30$ & $83,64 \pm 10,40$ & 0,584 \\
\multirow{4}{*}{ Perlakuan 1 } & Gula darah sewaktu & $203,50 \pm 68,50$ & $187,36 \pm 60,45$ & 0,132 \\
& Tekanan darah sistolik & $135,30 \pm 13,40$ & $126,93 \pm 8,86$ & $0,000^{*}$ \\
& Tekanan darah diastolik & $83,64 \pm 8,20$ & $81,21 \pm 8,29$ & 0,202 \\
\multirow{5}{*}{ Perlakuan 2 } & Gula darah sewaktu & $200,20 \pm 87,90$ & $175,54 \pm 64,87$ & $0,017^{*}$ \\
& Tekanan darah sistolik & $134,54 \pm 16,78$ & $125,45 \pm 16,78$ & $0,012^{*}$ \\
& Tekanan darah diastolik & $83,48 \pm 7,34$ & $78,48 \pm 6,06$ & $0,007^{*}$ \\
\hline Keterangan: Nilai & Gula darah sewaktu & $173,90 \pm 90,80$ & $148,97 \pm 47,80$ & 0,079 \\
\hline
\end{tabular}

Keterangan: Nilai $\mathrm{p}=$ nilai signifikansi. Analisis menggunakan paired sample t-test.

Rata-rata TDD dari ketiga kelompok juga menunjukkan adanya penurunan dari kunjungan pertama (pre) dan kunjungan kedua (post). Kelompok kontrol mengalami penurunan dari $84,70 \pm 8,3 \mathrm{mmHg}$ menjadi $83,64 \pm 10,40$ $\mathrm{mmHg}(\mathrm{p}=0,584)$, kelompok perlakuan 1 mengalami penurunan dari $83,64 \pm 8,2 \mathrm{mmHg}$ menjadi $81,21 \pm 8,29 \mathrm{mmHg}(\mathrm{p}=0,202)$, dan kelompok perlakuan 2 mengalami penurunan dari $83,48 \pm 7,34 \mathrm{mmHg}$ menjadi $78,48 \pm 6,06$ $\mathrm{mmHg}(\mathrm{p}=0,007)$. Hanya penurunan rata-rata TDD yang terjadi pada kelompok perlakuan 2 yang menunjukkan perbedaan signifikan ( $p$ $<0,05)$.

Rata-rata penurunan GDS pada kelompok perlakuan 1 menunjukkan nilai yang signifikan $(\mathrm{p}<0,05)$. Pada kelompok kontrol, terdapat penurunan GDS dari semula 203,5 $\pm 68,5 \mathrm{mg} /$ dL menjadi $187,36 \pm 60,45 \mathrm{mg} / \mathrm{dL}(\mathrm{p}=0,132)$, kelompok perlakuan 1 mengalami penurunan dari $200,2 \pm 87,9 \mathrm{mg} / \mathrm{dL}$ menjadi $175,54 \pm 64,87$ $\mathrm{mg} / \mathrm{dL}(\mathrm{p}=0,017)$, dan kelompok perlakuan 2 mengalami penurunan dari $173,9 \pm 90,8 \mathrm{mg} /$ dL menjadi $148,97 \pm 47,80 \mathrm{mg} / \mathrm{dL}(\mathrm{p}=0,079)$.

Tabel 6 menunjukkan penilaian TDS, TDD dan GDS pada kunjungan pertama (pre) dan kedua (post) antara kelompok kontrol dengan kelompok perlakuan 1, kelompok kontrol dengan kelompok perlakuan 2, dan kelompok perlakuan 1 dengan 2. Penurunan outcome klinis TDS, TDD dan GDS pada baseline (pre) tidak berbeda bermakna $(\mathrm{p}>0,05)$.

Tabel 6 Penilaian Data Kunjungan Pertama (Pre) dan Kunjungan Kedua (Post) Tekanan Darah dan Kadar Gula Darah Pasien Diabetes Melitus-Hipertensi Kelompok Kontrol dan Perlakuan

\begin{tabular}{|c|c|c|c|c|c|c|}
\hline \multirow[t]{2}{*}{ Variabel Penelitian } & $\begin{array}{c}\text { Kontrol } \\
\mathbf{N}=\mathbf{3 3}\end{array}$ & $\begin{array}{c}\text { Perlakuan } 1 \\
\mathbf{N}=\mathbf{3 3}\end{array}$ & $\begin{array}{c}\text { Perlakuan } 2 \\
\mathbf{N}=\mathbf{3 3}\end{array}$ & \multirow[t]{2}{*}{$\begin{array}{l}\text { Nilai } \\
\text { p(1) }\end{array}$} & \multirow[t]{2}{*}{$\begin{array}{l}\text { Nilai } \\
\text { p(2) }\end{array}$} & \multirow[t]{2}{*}{$\begin{array}{l}\text { Nilai } \\
\text { p(3) }\end{array}$} \\
\hline & $\operatorname{Mean} \pm \mathrm{SD}$ & $\operatorname{Mean} \pm \mathrm{SD}$ & $\operatorname{Mean} \pm \mathrm{SD}$ & & & \\
\hline \multicolumn{7}{|l|}{ Pre } \\
\hline Tekanan darah sistolik & $139,24 \pm 15,53$ & $135,30 \pm 13,40$ & $134,54 \pm 16,78$ & 0,299 & 0,216 & 0,841 \\
\hline Tekanan darah diastolic & $84,70 \pm 8,30$ & $83,64 \pm 8,20$ & $83,48 \pm 7,34$ & 0,590 & 0,538 & 0,939 \\
\hline Gula darah sewaktu & $203,50 \pm 68,50$ & $200,20 \pm 87,90$ & $173,90 \pm 90,80$ & 0,874 & 0,151 & 0,200 \\
\hline \multicolumn{7}{|l|}{ Post } \\
\hline Tekanan darah sistolik & $132,87 \pm 12,81$ & $126,93 \pm 8,86$ & $125,45 \pm 16,78$ & $0,025^{*}$ & $0,007 *$ & 0,651 \\
\hline Tekanan darah diastolic & $83,64 \pm 10,40$ & $81,21 \pm 8,29$ & $78,48 \pm 6,06$ & 0,246 & $0,015^{*}$ & 0,192 \\
\hline Gula darah sewaktu & $187,36 \pm 60,45$ & $175,54 \pm 64,87$ & $148,97 \pm 47,80$ & 0,411 & $0,009 *$ & 0,066 \\
\hline
\end{tabular}

Keterangan: Nilai $\mathrm{p}(1)=$ nilai signifikansi antara kelompok kontrol dan perlakuan 1. Nilai $\mathrm{p}(2)=$ nilai signifikansi antara kelompok kontrol dan perlakuan 2; Nilai $\mathrm{p}(3)=$ nilai signifikansi antara kelompok perlakuan 1 dan $2 . *=$ nilai $\mathrm{p}<0,05$. Analisis menggunakan uji Anova dengan Pos Hoc test. 


\section{Pembahasan}

Mayoritas pasien pada penelitian ini adalah perempuan, baik pada kelompok kontrol, kelompok perlakuan 1 yang mendapat brief counseling, maupun kelompok perlakuan 2 yang mendapatkan brief counseling + pesan motivatif. Hal ini sejalan dengan penelitian Ballotari et al. (2015) di Italia yang menunjukkan bahwa pasien yang memiliki DM didominasi oleh pasien perempuan yaitu sebanyak 206.201 pasien. ${ }^{14}$

Konseling singkat (brief counseling) memiliki kelebihan pada efisiensi waktu dan kepraktisannya, sebab telah terdapat indikator penilaian terhadap kondisi pasien. ${ }^{15,16}$ Metode brief counseling 5A modifikasi dinilai cukup praktis untuk digunakan dalam konseling pada pasien DM-hipertensi, karena metode ini dapat menilai sejauh mana pengetahuan dan kepatuhan pasien dalam berobat melalui tahapan 5A yang terdiri dari assess (menilai), advise (memberi saran), agree (persetujuan), assist (membantu), dan arrange (tindak lanjut).

Penilaian (assess) yang dilakukan terhadap perilaku berobat pasien berupa tingkat perilaku prekontemplasi, kontemplasi, persiapan, dan aksi. Melalui metode brief counseling 5A modifikasi, setelah bertemu dengan konselor, pasien diharapkan agar dapat memutuskan secara bersama untuk melakukan tindakan/ perilaku berobat yang baik, yaitu dari tingkat prekontemplasi, kontemplasi, atau persiapan dapat berubah menjadi tingkat aksi. Metode ini tidak membutuhkan waktu yang relatif lama sehingga praktis dalam penerapannya. Adapun isi/konten dari brief counseling 5A modifikasi adalah edukasi terkait manajemen DM tipe 2, komplikasi dari DM-hipertensi, efek samping hipoglikemik, penggunaan obat antidiabetik oral dan obat antihipertensi, kepatuhan terapi, diet dan olahraga.

Perubahan perilaku yang terlihat pada tahap aksi (Tabel 2) menunjukkan peningkatan ratarata aspek kognitif (pengetahuan), afektif dan psikomotorik. Adapun aspek psikomotorik meliputi kepatuhan terapi, diet (karbohidrat/ glukosa dan garam), olahraga atau modifikasi lifestyle. Hal ini sejalan dengan penelitian Farsaei et al. (2011) bahwa pemberian edukasi oleh farmasis disertai dengan diabetes diary log sebagai pengingat minum obat dapat meningkatkan glikemik kontrol (HbA1c). Edukasi farmasis terkait manajemen DM tipe 2 dan motivasi kepatuhan terapi dapat meningkatkan pengetahuan dan pengontrolan gula darah pasien. ${ }^{7}$

Penelitian meta analisis juga menunjukkan pemberian intervensi pengingat (reminder) secara signifikan meningkatkan kepatuhan pasien lebih besar dibandingkan kelompok kontrol (66.61\% dibandingkan 54.71\%). ${ }^{19}$ Hasil penelitian di Saudi Arabia oleh Khan et al. (2015) menunjukkan bahwa kesadaran terhadap penyakit DM dan pengetahuan pasien DM berpengaruh pada outcome klinis pasien dalam pengontrolan $\mathrm{HbA} 1 \mathrm{c}$ dan $\mathrm{BMI} .{ }^{17}$

Outcome klinis dari pasien DM-hipertensi dapat dilihat dari pengukuran kadar gula darah sewaktu (GDS) dan tekanan darah (TD) yang ditunjukkan pada Tabel 4 dan 5. Rata-rata TDS maupun TDD ketiga kelompok mengalami penurunan dari kunjungan pertama (pre) dan kedua (post) (Tabel 5). Penurunan hasil rata-rata TDS menunjukkan perbedaan yang signifikan $(\mathrm{p}<0,05)$, sedangkan penurunan rata-rata TDD yang menunjukkan perbedaan signifikan $(\mathrm{p}<0,05)$ hanya ditemukan pada kelompok perlakuan 2. Rata-rata penurunan kadar GDS kelompok 1 menunjukkan nilai yang signifikan $(p<0,05)$. Hal ini sejalan dengan penelitian Swaroop et al. (2016) di India yang menunjukkan bahwa intervensi konseling farmasis mampu meningkatkan pengontrolan kadar GDS. ${ }^{18}$

Penilaian antara kelompok kontrol dan perlakuan 1, antara kelompok kontrol dan perlakuan 2, serta antara kelompok perlakuan 1 dan 2 ditunjukkan pada Tabel 6. Penurunan outcome klinis TDS, TDD dan GDS pasien 
pada baseline (pre) tidak berbeda bermakna $(\mathrm{p}>0,05)$. Penurunan TDD antara kelompok kontrol dan perlakuan $1(\mathrm{p}=0,025)$, serta antara kelompok kontrol dan kelompok perlakuan 2 $(p=0,07)$ menunjukkan penurunan bermakna $(p<0,05)$. Hal ini menunjukkan bahwa terdapat efektivitas intervensi, baik intervensi yang berupa brief counseling 5A modifikasi maupun brief counseling 5A modifikasi yang disertai pesan motivasi, terhadap pengontrolan TDS. Penurunan yang signifikan dari TDD hanya ditemukan pada penilaian antara kelompok kontrol dan kelompok perlakuan $2(\mathrm{p}=0,015)$. Sebaliknya, pada penilaian antara kelompok kontrol dan kelompok perlakuan 1 ataupun antara kelompok perlakuan 1 dan kelompok perlakuan 2 tidak ditemukan perbedaan yang bermakna $(p>0,05)$. Sama halnya dengan TDD, penurunan GDS yang terjadi antara kelompok kontrol dan kelompok perlakuan 2 menunjukkan perbedaan yang bermakna $(p=0,009)$, sedangkan penurunan GDS antara kelompok kontrol dan kelompol perlakuan 1, ataupun antara kelompok perlakuan 1 dan kelompok perlakuan 2 tidak menunjukkan perbedaan bermakna. Hal ini sejalan dengan hasil penelitian oleh Swaroop et al. (2016) di India yang menunjukkan bahwa intervensi konseling farmasis mampu menurunkan kadar GDS, ${ }^{18}$ begitu pula dengan hasil penelitian Farsaei et al. (2011) bahwa edukasi tentang obat antidiabetik oral, kepatuhan, diabetes dairy log dan pill box secara signifikan mampu menurunkan GDS $(\mathrm{p}<0,001)$ pada kelompok kontrol dan perlakuan. ${ }^{7}$ Pemberian SMS sebagai reminder juga menunjukkan pengaruh positif terhadap outcome klinis pasien. $^{19}$

\section{Simpulan}

Brief counseling 5A modifikasi disertai pesan motivasi oleh farmasis dapat meningkatkan tingkat perilaku pasien DM-hipertensi yakni dari aspek pengetahuan, kepatuhan berobat, modifikasi lifestyle serta outcome klinis pasien.

\section{Ucapan Terima Kasih}

Terima kasih disampaikan kepada Fakultas Farmasi Universitas Ahmad Dahlan dan RSUD Panembahan Senopati Bantul, Yogyakarta, yang telah memberikan izin terlaksananya penelitian ini, serta kepada seluruh responden pasien DM-hipertensi rawat jalan di RSUD Panembahan Senopati, Bantul, Yogyakarta, dan seluruh tim konselor apoteker.

\section{Pendanaan}

Penelitian ini memperoleh dana hibah dari Kementerian Riset, Teknologi dan Pendidikan Tinggi Republik Indonesia

\section{Konflik Kepentingan}

Seluruh penulis menyatakan tidak terdapat potensi konflik kepentingan dengan penelitian, kepenulisan (authorship), dan atau publikasi artikel ini.

\section{Daftar Pustaka}

1. World Health Organization. Global status report on noncommunicable diseases [diakses 1 Juni 2019]. Tersedia dari: http:// www.who.int/nmh/publications/ncd_rep ort2010/en/

2. Chow EP, Hassali MA, Saleem F, Aljadhey H. Effects of pharmacist-led patient education on diabetes-related knowledge and medication adherence: A home-based study. Health Educ J. 2015;75(4):421-33. doi: 10.1177/0017896915597021

3. Tadesse K, Amare H, Hailemariam T, Gebremariam T. Prevalence of hypertension among patients with type 2 diabetes mellitus and its socio demographic factors in Nigist Ellen Mohamed Memorial Hospital Hosanna, Southern Ethiopia. J Diabetes 
Metab. 2018;9(4):792. doi: 10.4172/21556156.1000792

4. Daoud N, Osman A, Hart TA, Berry EM, Adler B. Self-care management among patients with type 2 diabetes in East Jerusalem. Health Educ J. 2014;74(5):603 -15. doi: 10.1177/0017896914555038

5. Khattab M, Khader YS, Al-Khawaldeh A, Aljouni K. Factors associated with poor glycemic control among patients with type 2 diabetes. J Diabetes Complications. 2010;24(2):84-9. doi: 10.1016/j.jdiacomp. 2008.12.008.

6. Ozcelik F, Yiginer O, Arslan E, Serdar MA, Uz O, Kardesoglu E, Kurt I. Association between glycemic control and the level of knowledge and disease awareness in type 2 diabetic patients. Pol Arch Med Wewn. 2010;120(10):399-406.

7. Farsaei S, Sabzghabaee AM, Zargarzadeh AH, Amini M. Effect of pharmacist-led patient education on glycemic control of type 2 diabetics: A randomized controlled trial. J Res Med Sci. 2011;16(1):43-9.

8. Malathy R, Narmadha M, Ramesh S, Alvin JM, Dinesh BN. Effect of a diabetes counseling programme on knowledge, attitude and practice among diabetic patients in Erode district of South India. J Young Pharm. 2011;3(1):65-72. doi: 10. 4103/0975-1483.76422.

9. Smith M. Pharmacists' role in improving diabetes medication management. J Diabetes Sci Technol. 2009;3(1):175-9. doi: 10.1177/193229680900300120

10. Mini KV, Ramesh A, Parthasarathi G, Mothi SN, Swamy VT. Impact of pharmacist provided education on medication adherence behaviour in HIV/AIDS patients treated at a non-government secondary care hospital in India. J AIDS HIV Res. 2012;4(4):94-9. doi: 10.5897/JAHR11.027

11. Venkatesan R, Devi AS, Parasuraman S, Sriram S. Role of community pharmacists in improving knowledge and glycemic control of type 2 diabetes. Perspect Clin Res. 2012;3(1):26-31. doi: 10.4103/22293485.92304.

12. Armor BL, Britton ML, Dennis VC, Letassy NA. A review of pharmacist contributions to diabetes care in the United States. J Pharm Pract. 2010;23(3):250-64. doi: $10.1177 / 0897190009336668$

13. Saputri GZ, Akrom, Darmawan E. Improving outpatient's quality of life via patient adherence of antihypertensive therapy using "mobile phone (SMS) and brief counseling $5 \mathrm{~A}$ " in polyclinic of internal medicine at PKU Muhammadiyah Bantul Hospital, Yogyakarta. Indones J Clin Pharm. 2017;6(2):67-77. doi: 10.15 416/ijcp.2017.6.2.67

14. Ballotari P, Ranieri SC, Luberto F, Caroli S, Greci M, Giorgi Rossi P, et al. Sex differences in cardiovascular mortality in diabetics and nondiabetic subjects: A population-based study (Italy). Int $\mathrm{J}$ Endocrinol. 2015;2015:914057. doi: 10.1 155/2015/914057

15. Vallis M, Piccinini-Vallis H, Sharma AM, Freedhoff Y. Modified 5 As: Minimal intervention for obesity counseling in primary care. Can Fam Physician. 2013; 59(1):27-31.

16. Alfian R. Layanan pesan singkat pengingat untuk meningkatkan kepatuhan dan menurunkan tekanan darah pasien hipertensi di RSUD Dr. H. Moch Ansari Saleh Banjarmasin. Media Farmasi. 2014; 11(2):189-96. doi: 10.12928/mf.v11i2.18 78

17. Khan NA, Venkathachalam VV, Al Akhali KM, Alavuden SS, Dhanapal CK, Mohammad AAS. Overview of glycemic control, knowledge, awareness and attitude among type-2 diabetes male patient's. J App Pharm. 2015;7(1):75-82.

18. Swaroop AM, Varghese C, Jose J, Maheswari E, Kalra P. Impact of patient counselling on knowledge, attitude, practice 
and medication adherence in type 2 diabetes mellitus patients. Eur J Pharm Med Res. 2016;3(4):231-5.

19. Fenerty SD, West C, Davis SA, Kaplan
SG, Feldman SR The effect of reminder systems on patients' adherence to treatment. Patient Prefer Adherence. 2012;6:127-35. doi: 10.2147/PPA.S26314 